\title{
ANALYSIS OF THE PROVISION OF RIVER DOCKS ON THE MUSI RIVER BASED ON PASSENGERS AND GOODS TRIP GENERATION
}

\author{
Indah Novianty ${ }^{1}$, Yosi Pahala ${ }^{2}$, Sri Rahardjo ${ }^{3}$, Wawan Darwan ${ }^{4}$ \\ 1. STMT Trisakti, 2. STMT Trisakti, 3. STMT Trisakti, 4. Kementerian \\ Perhubungan Republik Indonesia \\ $\triangle$ corresponding author: humairah_pooh@yahoo.co.id
}

\begin{abstract}
Musi River is a leading tourist destination in the city of Palembang and has a huge potential to be developed. It has 33 attracting places that can be accessed by boat. The purpose of this research is to know the level of requirement of river stop at Musi River Palembang City from supply and demand side so that can be identified what things need to be improved of its service to boast the existence of the river stop as a part of transportation system in Palembang city especially in tourism field. This study uses a method of generating motion, i.e. modeling stages that estimate the number of movements coming from a zone and the amount of movement that is attracted to a zone. This research needs a study about performance of river transportation in city. It requires a plan as an effort to increase the activity of river transportation as an alternative transportation to reduce road network load. In addition, it is necessary to plan the integration of inter-modal (river and land transportation), so that there will be ease of connection for river transportation users who will continue their journey using land transportation and vice versa and as well as efforts to increase the attractiveness of river transportation by combining the concept of waterfront city.
\end{abstract}

Keywords: Trip Generation, River Transportation, River Docks.

\section{Introduction}

Transportation plays an important role in the development of a country. Basically, the function of the transport system and its facilities is to connect one place to another apart with the various mechanisms contained therein, as land transportation also plays an important role in the development of a city (Kadarisman, 2016, Najoan, 2016). Prasadja (2017) discussed the growing use of transportation in tourism activities in Indonesia. Balen (2014) developed a scenario planning method to assess the potential economic impacts of river tourism on a port region. Kadarisman (2016) conducted a descriptive-qualitative study to analyze the development policy of sea freight transport. In general, river transportation in Indonesia is used to serve the mobility of goods and passengers, loading and unloading cargo (Brata, 2016). 
River transportation not only plays an important role in the rural, but also in the developed areas. The river transport used initially in the form of a bamboo raft or large wooden rod formed by making a hole in the middle. Along with the development of the age of human thought slowly progressed to create various types of boats ranging from bamboo raft, boat mortar, canoe, to a boat that uses engine power. The river has a big role in the development activities, especially for rural areas and areas surrounded by rivers such as South Sumatra. River if utilized properly and optimally can help to overcome inequality among region especially in infrastructure aspect.

River resources in some areas are potentials that can be utilized as regional transportation infrastructure. This is supported by the geographical condition that is owned by several provinces in Indonesia where the potential of river resources is quite a lot and can be utilized as a means of transportation. River transport has several advantages compared to other modes, while the advantages are as follows. First, there is no need to make or build water way because the river as the infrastructure is naturally available and maintenance of infrastructure is not too costly. Second, river treatment is much lighter and cheaper than caring for roads because rivers only need signs and dredging. The importance of River transportation could reach the rural with the dominance of the waters. Chen et.al (2017) present current stressors, environmental and ecological status and challenges in the Yangtze River Economic Belt, and offer policy recommendations on how to include ecological conservation into its development.

This paper will present a pattern of revival of the movement of the use of river transportation mode in the Musi River Palembang City, so that it can be used as a reference in the construction of the dock. With the identification of the passengers' and goods' generated and attracted trip, the docks can be developed efficiently and optimally in supporting the activities of urban communities.

According to Miro (2005) transportation is an attempt to transport or move goods or passengers from a place to other places. Meanwhile, according to Miro (2005) transportation is defined as the effort to move, transport or 
transfer objects from one place to another, so the object becomes more useful or useful for a purpose. The supporting tools used for performing such activities vary depending on the shape of the object to be moved, the distance between the place and the object, and the purpose of the object to be moved. Transport business is not just a movement of goods and people from other places in a static manner and condition, but the transportation is always in accordance with technological developments. The market relations impose to river transport, the strict requirements on acceleration of cargo and passenger delivery at the smallest costs of transportation are on decrease of the transport component in prime cost of production, on improvement of quality and reliability of transportations (Kondolf, 2017).

Three things that make the nation great and prosperous, namely fertile land, hard work, and smooth transportation, both people and goods from one country to another (Nasution, 2004). Transportation plays an important role for both individuals, the public, economic and socio-political growth of a country. Nasution (2004) mentions that transportation can create and increase accessibility of previously untapped and untreatable potential of natural resources. Progress of transportation will also lead to increased mobility of people, where the higher the mobility will be the higher the level of productivity. With the increase in productivity, it will have an impact on economic progress.

Palembang is the capital of South Sumatra Province. Palembang is the second largest city on the island of Sumatra. Palembang city has an area of $400.61 \mathrm{~km} 2$. Palembang City location is quite strategic because it is traversed by the path crossing the island of Sumatra that connects between regions on the island of Sumatra. In addition, in the city of Palembang also there is Musi River that serves as a means of transportation and trade between regions.

River transportation is a common mode of transportation for the community, many activities carried out by people using river transportation such as schools, work, tourism to conduct trading activities known as floating market. River transportation in Indonesia is generally used to serve the mobility of goods and passengers, both along the river and river crossings. 
Mulyana (2005) stated that the navigable river water system must meet the technical requirements, namely: depth, flexibility, and certain current speed, so that it is safe and easy to navigate.

Musi River sailing channel is in South Sumatra Province and is located in several regional administration areas such as Palembang City, Musi Banyuasin Regency and Banyuasin Regency. Musi River voyage flow has a total length of up to $720 \mathrm{~km}$ with a variation of river flow width of $200 \mathrm{~m}$ to 2,749 $\mathrm{m}$. The main port on the Musi river is the main port of Boombaru in Palembang City. This harbor is located about $90.33 \mathrm{~km}$ from the mouth of the Musi river in Tanjung Buyut. The main activity of Musi River transportation today is from Sungsang corridor to Palembang generally to serve cargo of PT. Pupuk Sriwijaya, PT. Pertamina RIP III Plaju, PT. Sinar Alam Permai, coal load, cement load, CPO load, container as well as daily interest of local community and transmigration area. The names of the docks and their locations in Palembang City are presented in Figure 2.1.

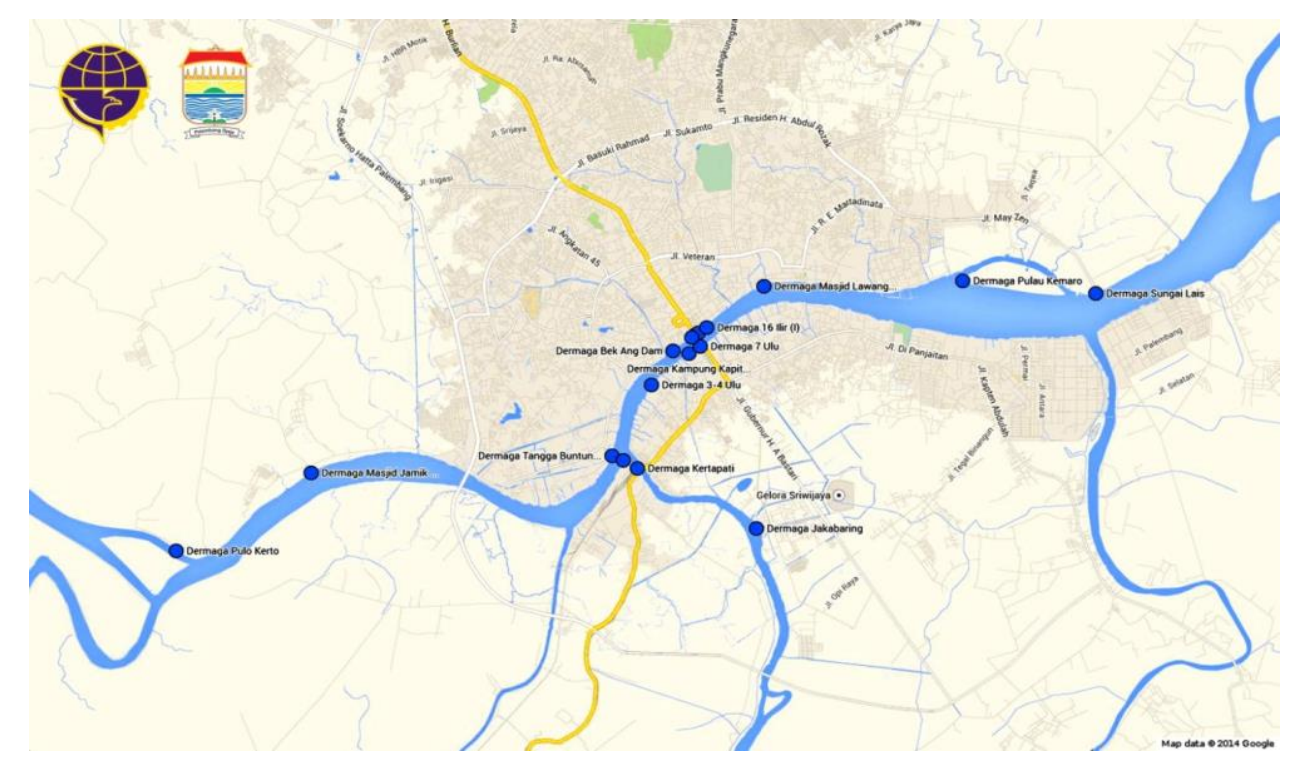

Figure 1. Map Location docks along Musi River Palembang City. 


\section{Method}

Demand and supply analysis of river transportation will be done is to see the great movement of passengers and goods using the model of the trip generation and attraction. This study uses a method of generating motion, i.e. modelling stages that estimate the number of movements coming from a zone and the amount of movement that is attracted to a zone. The magnitude of the movement depends on the model generated and the support of actual movement data. The analysis of demand and supply that will be done is with the growth trend pattern of passenger and goods movement by using the model of the trip generation and attraction. The magnitude of the movement depends on the model generated and the support of actual movement data. From the trip generation and attraction of the resulting movement will then be estimated to the number of movement of passengers and goods in the next 20 years. Based on the characteristics of the movement of passengers and goods in the study area, the calculation of the movement of passengers and goods using the model of trip generation and attraction with regression analysis with the following general form (Tamim, 1997)

$Y_{e i}=a+b_{1 i} x_{1 i}+b_{2 i} x_{2 i}+b_{3 i} x_{3 i}+\ldots+b_{n i} x_{n i}$

Where $Y_{e i}$ denotes the number of trips that are generated or are attracted from and to $i$-th zone as a variable bound to the model concerned. Whereas $x_{n i}$ is the amount of free variable to $n$ observed from $i$-th zone. The a, $b$ is the constant to be derived from the calculation and $b_{n i}$ is the partial regression coefficient. Activities conducted are macro then some specified free variables are not derived from the primary survey results, but the secondary survey sourced from the potential of the village in 2013. As for some variables used in the analysis are:

$\mathrm{Xi}$ : population

$\mathrm{X}_{2 \mathrm{i}}$ : number of families

$\mathrm{X}_{3 \mathrm{i}}$ : Number of Junior High Schools

$\mathrm{X}_{4 \mathrm{i}}$ : Number of Senior High School 
$\mathrm{X}_{5 \mathrm{i}}$ : Number of Hospitals

$\mathrm{X}_{6 \mathrm{i}}$ : number of Posyandu

$\mathrm{X}_{7 \mathrm{i}}$ : Number of Puskesmas

$\mathrm{X}_{8 \mathrm{i}}$ : Area of Rice Farming

$\mathrm{X}_{9 \mathrm{i}}$ : Garden Area

$\mathrm{X}_{10 \mathrm{i}}$ : Non-agricultural land area

$\mathrm{X}_{11 \mathrm{i}}$ : number of markets

$\mathrm{X}_{12 \mathrm{i}}$ : Number of Recreation Sites

$\mathrm{X}_{13 \mathrm{i}}$ : Revenue Value Original (PAD)

Some of these variables must be determined in some areas that use river transportation as the mode of transportation. Based on the results of regression analysis conducted, it can be known some models of the trip generation of each province in Indonesia, which can then be known the value of the trip generation of passengers and goods using river transport.

\section{Discussions and Result}

The river transportation in South Sumatera Province was developed into 11 river corridor developments, where the value of the goods transport movement in South Sumatera Province was the largest in corridor 10, as well as the pull of goods in South Sumatera province, the biggest attraction was in corridor 10. For more details can be seen in the table below.

Table 1. Value of river transport goods generation and attraction Province of South Sumatera Year 2013.

\begin{tabular}{llll}
\hline Province & Corridor & \multicolumn{2}{c}{2013} \\
\cline { 3 - 4 } & & Generation & Attraction \\
\hline South Sumatera & Corridor 1 & 288.564 & 279.355 \\
& Corridor 2 & 267.953 & 259.402 \\
& Corridor 3 & 362.867 & 351.287 \\
& Corridor 4 & 326.455 & 316.037 \\
& Corridor 5 & 357.853 & 346.433 \\
& Corridor 6 & 268.362 & 259.798 \\
& Corridor 7 & 292.422 & 283.090 \\
\hline
\end{tabular}


Table 1, Cont. Value of river transport goods generation and attraction Province of South Sumatera Year 2013.

\begin{tabular}{llll}
\hline Corridor 8 & $\mathbf{2 8 8 . 6 9 6}$ & $\mathbf{2 7 9 . 4 8 3}$ \\
\hline Corridor 9 & 240.943 & 233.253 \\
Corridor 10 & 381.201 & 369.036 \\
& Corridor 11 & 352.413 & 341.166 \\
\hline
\end{tabular}

The number of movements that identify the characteristics of passenger and goods travel using river mode in the next 20 years is calculated based on movement data in 2013. The assumptions used to projecting over the next 20 years are based on several variables that affect the regression model that has been done. The result of projection of goods movement in South Sumatera Province in the next 20 years shows that the rise of goods in South Sumatera Province is decreasing and there is also an increase in movement, which can be shown in the picture below.

Table 2. Value of generation and attraction of river transport goods Province of South Sumatera year 2013-2033

\begin{tabular}{lllllllllll}
\hline Corridor & $\mathbf{2 0 1 3}$ & & $\mathbf{2 0 1 8}$ & & $\mathbf{2 0 2 3}$ & & $\mathbf{2 0 2 8}$ & & $\mathbf{2 0 3 3}$ \\
& & & & & & & & \\
& Generation & Attraction & Generation & Attraction & Generation & Attraction & Generation & Attraction & Generation & Attraction \\
\hline Corridor 1 & 288.564 & 279.355 & 288.385 & 279.182 & 288.207 & 279.009 & 288.028 & 278.837 & 287.612 & 278.434 \\
Corridor 2 & 267.953 & 259.402 & 269.383 & 260.786 & 270.824 & 262.181 & 272.274 & 263.585 & 275.691 & 266.893 \\
Corridor 3 & 362.867 & 351.287 & 365.761 & 354.088 & 368.686 & 356.921 & 371.640 & 359.780 & 378.633 & 366.550 \\
Corridor 4 & 326.455 & 316.037 & 330.588 & 320.038 & 334.795 & 324.110 & 339.065 & 328.245 & 349.264 & 338.118 \\
Corridor 5 & 357.853 & 346.433 & 362.214 & 350.655 & 366.650 & 354.949 & 371.151 & 359.307 & 381.890 & 369.703 \\
Corridor 6 & 268.362 & 259.798 & 268.667 & 260.093 & 268.972 & 260.389 & 269.278 & 260.685 & 269.994 & 261.378 \\
Corridor 7 & 292.422 & 283.090 & 292.255 & 282.928 & 292.088 & 282.766 & 291.920 & 282.605 & 291.531 & 282.227 \\
Corridor 8 & 288.696 & 279.483 & 288.875 & 279.656 & 289.054 & 279.829 & 289.232 & 280.002 & 289.650 & 280.407 \\
Corridor 9 & 240.943 & 233.253 & 239.287 & 231.650 & 237.646 & 230.063 & 236.020 & 228.488 & 232.271 & 224.859 \\
Corridor 10 & 381.201 & 369.036 & 378.334 & 366.261 & 375.497 & 363.514 & 372.686 & 360.793 & 366.216 & 354.529 \\
Corridor 11 & 352.413 & 341.166 & 352.865 & 341.604 & 353.318 & 342.042 & 353.771 & 342.482 & 354.832 & 343.509 \\
\hline
\end{tabular}

The river transport in South Sumatera Province was developed into 11 developments of river corridor. The greatest value of passenger movement in South Sumatera Province is in corridor 10, so also with the attraction of passengers in South Sumatera province where the biggest passenger pull is in corridor 10. For more details can be seen in the table below. 
Table 3. Value of generation and attraction of passenger transportation of river Province of South Sumatera year 2013.

\begin{tabular}{llll}
\hline Province & Corridor & 2013 & \\
\hline & & Generation & Attraction \\
\hline South & Corridor 1 & 7.874 .640 & 7.669 .919 \\
& & & \\
& Corridor 2 & 7.312 .169 & 7.122 .071 \\
& Corridor 3 & 9.902 .299 & 9.644 .864 \\
& Corridor 4 & 8.908 .649 & 8.677 .046 \\
& Corridor 5 & 9.765 .460 & 9.511 .583 \\
& Corridor 6 & 7.323 .340 & 7.132 .952 \\
& Corridor 7 & 7.979 .925 & 7.772 .467 \\
& Corridor 8 & 7.878 .242 & 7.673 .428 \\
& Corridor 9 & 6.575 .089 & 6.404 .153 \\
& Corridor 10 & 10.402 .606 & 10.132 .165 \\
& Corridor 11 & 9.617 .001 & 9.366 .984 \\
\hline
\end{tabular}

The number of movements that identify the characteristics of passenger and goods travel using river mode in the next 20 years is calculated based on movement data in 2013. The assumptions used to projecting over the next 20 years are based on several variables that affect the regression model that has been done.

The result of projection of passenger movement in South Sumatera Province in the next 20 years shows that there is a rise of passengers that experienced an increase and there is also a decrease. The decreasing movement of passengers in corridors $1,7,9$, and 10, while other corridors have increased movement. The generation and attraction of the highest passenger movement for the next 20 years in South Sumatera Province is located in corridor 5. The activities of the population in the corridor are certainly a factor influencing the magnitude of the movement and the pattern of river transportation movement. Based on the results of the analysis that can be seen there are still the number of families living on the banks of the river which is relatively high and there are villages that left behind. Other factors affecting the magnitude of the generating value in the corridor are the national port and the national activity center which became one of the triggers of the hike in corridor 1 . 
Table 4. Magnitude value of passengers and attraction of river transport passengers of South Sumatra Province year 2013-2033.

\begin{tabular}{|c|c|c|c|c|c|c|c|c|c|c|}
\hline \multirow[t]{2}{*}{ Corridor } & \multicolumn{2}{|l|}{2013} & \multicolumn{2}{|l|}{2018} & \multicolumn{2}{|l|}{2023} & \multicolumn{2}{|l|}{2028} & \multicolumn{2}{|l|}{2033} \\
\hline & Generation & Attraction & Generation & Attraction & Generation & Attraction & $\begin{array}{l}\text { Generation } \\
\end{array}$ & Attraction & Generation & Attraction \\
\hline Corridor 1 & 7.874 .640 & 7.669 .919 & 7.869 .761 & 7.665 .167 & 7.864 .886 & 7.660 .419 & 7.860 .015 & 7.655 .674 & 7.855 .148 & 7.650 .934 \\
\hline Corridor 2 & 7.312 .169 & 7.122 .071 & 7.351 .200 & 7.160 .088 & 7.390 .524 & 7.198 .389 & 7.430 .101 & 7.236 .937 & 7.469 .975 & 7.275 .774 \\
\hline Corridor 3 & 9.902.299 & 9.644 .864 & 9.981 .254 & 9.287 .148 & 10.061 .093 & 8.947 .771 & 10.141 .700 & 8.623 .168 & 10.223 .213 & 8.314 .848 \\
\hline Corridor 4 & 8.908 .649 & 8.677.046 & 9.021 .431 & 8.786 .896 & 9.136 .220 & 8.898 .701 & 9.252 .766 & 9.012 .218 & 9.371 .403 & 9.127 .770 \\
\hline Corridor 5 & 9.765 .460 & 9.511 .583 & 9.884 .472 & 9.627 .501 & 10.005 .523 & 9.745 .404 & 10.128 .357 & 9.865 .045 & 10.253 .311 & 9.986 .751 \\
\hline Corridor 6 & 7.323 .340 & 7.132 .952 & 7.331 .664 & 7.141 .059 & 7.340 .000 & 7.149 .179 & 7.348 .348 & 7.157 .310 & 7.356 .710 & 7.165 .454 \\
\hline Corridor 7 & 7.979 .925 & 7.772.467 & 7.975 .356 & 7.768 .016 & 7.970 .790 & 7.763 .570 & 7.966 .228 & 7.759 .126 & 7.961 .669 & 7.754 .685 \\
\hline Corridor 8 & 7.878 .242 & 7.673.428 & 7.883 .115 & 7.678 .173 & 7.887.991 & 7.682 .923 & 7.892 .871 & 7.687.676 & 7.897 .755 & 7.692 .433 \\
\hline Corridor 9 & 6.575 .089 & 6.404 .153 & 6.529 .898 & 6.360 .137 & 6.485 .141 & 6.316 .544 & 6.440 .752 & 6.273 .308 & 6.396 .787 & 6.230 .486 \\
\hline Corridor10 & 10.402 .606 & 10.132 .16 & 10.324 .374 & 10.055 .96 & 10.246 .963 & 9.980 .567 & 10.170 .247 & 9.905 .846 & 10.094 .334 & 9.831 .906 \\
\hline Corridor 11 & 9.617 .001 & 9.366 .984 & 9.629 .339 & 9.379 .000 & 9.641 .699 & 9.391 .039 & 9.654 .078 & 9.403 .096 & 9.666 .479 & 9.415 .175 \\
\hline
\end{tabular}

\section{Conclusion}

This study has analyzed the large increase of passengers and goods in the Musi River until 2033. From this analysis it is found that passengers and goods tends to increase significantly. From the analysis results, it is obtained that the increasing number of passengers and goods occurred around the city of Palembang is generally for tourist destinations. The result of projection of passenger movement in South Sumatera Province in the next 20 years shows that there is an increasing of passengers. The movement using river transportation in the Musi River Palembang City experienced a shift that tends to land transportation, but for certain trips located on the river route the use of river transportation is still in demand. The occurrence of this shift due to changes in land use and the availability of road network, is also due to the availability of various alternative modes that can be selected to support the movement. Selection of the mode is not only based on the consideration of travel time, but also consideration of the costs and conditions of availability of existing modes of transportation on the way to travel. It is necessary to plan the integration of inter-modal, river and land transportation, so that there will be ease of connection for river transportation users who will continue their journey using land transportation and vice versa, as well as efforts to increase the attractiveness of river transportation by combining the concept of waterfront city. 


\section{References}

Anatoliy Nyrkov, Anatoliy Shnurenko, Sergei Sokolov, Sergei Chernyi, Vitaliy Korotkov.(2017). Some Methods of Increasing the Efficiency of River Transport System. Procedia Engineering vol, 178 pp 543 - 550.

Brata Wuntara Umagapi, Siska Amonalisa, Lies Lesmini (2016). Kualitas pelayanan dokumen dan kecepatan bongkar muat cargo. Jurnal Manajemen Transportasi dan Logistik Vol.03. pp 379-386.

Kadarisman, Muh, Yuliantini, Suharto Abdul Majid. (2016). Formulasi Kebijakan system transportasi laut. Jurnal Manajemen Transportasi dan Logistik Vol.03. pp 161-183.

Kadarisman, Muh, Aang Gunawan, Ismiyati. (2016). Kebijakan Manajemen Transportasi darat dan dampaknya terhadap perekonomian masyarakat di Kota Depok. Jurnal Manajemen Transportasi dan Logistik Vol.03. pp 1-17.

Kondolf G. Mathias, Pedro J. Pinto. (2017). The social connectivity of urban rivers. Geomorphology 277. 182-196. http://dx.doi.org/10.1016/j.geomorph.2016.09.028

Mitchell van Balen, Michael Dooms, Elvira Haezendonc Mitchell van Balen, Michael Dooms, Elvira Haezendonc. (2014). River tourism development: The case of the port of Brussels. Research in Transportation Business \& Management 13. 71-79. http://dx.doi.org/10.1016/-j.rtbm.2014.10.014.

Miro, F. 2005. Perencanaan Transportasi. Jakarta: Erlangga

Mulyana, A. Taufik. 2005. Transportasi Air. Diktat Kuliah. Banjarmasin: Fakultas Teknik Universitas Lambung Mangkurat.

Najoan, D, Pahala. Y, Yunandyan, K.I. 2016. Hubungan biaya material kapal terhadap laba operasi. Jurnal Manajemen Transportasi dan Logistik Vol.02. pp 276-286.

Nasution, M., N. 2004. Manajemen Transportasi (Edisi Kedua). Jakarta: Ghalia Indonesia.

Ofyar Z Tamim. (1997). Perencanaan dan Pemodelan Transportasi. (edisi pertama). Bandung. Penerbit ITB.

Prasadja Ricardianto, Gunawan Djajaputra, Martono (2017). Air transport and tourism in Indonesia. IOSR journal of Applied Chemistry. Vol. 10. Pp 01-19.DOI: 10.9790/5736-1005010119.

Podevins, O. (2007) Sea Port system and the inland terminals network in the enlarged European Union. 2007 International Symposium on Logistics and Industrial Informatics, pp. 151-155.

Yushun Chen, Shuanghu Zhang, Desheng Huang, Bai-Lian Li, Junguo Liu, Wenjin Liu, Jing Mab, Fang Wang, Yong Wangg, Shengjun Wuh, Yegang Wui, Jinyue Yan, Chuanbo Guo, Wei Xin, Hao Wang. (2017). The development of China's Yangtze River Economic Belt: how to make it in a green way? Science Bulletin 62. 648-651. http://dx.doi.org/10.1016/-j.scib.2017.04.009. 